\title{
Gordonia otitidis sp. nov., isolated from a patient with external otitis
}

\author{
Soji lida, ${ }^{1}$ Hiroko Taniguchi, ${ }^{1}$ Akiko Kageyama, ${ }^{1}$ Katsukiyo Yazawa, ${ }^{1}$ \\ Hiroji Chibana, ${ }^{1}$ Shota Murata, ${ }^{2}$ Fumio Nomura, ${ }^{3}$ Reiner M. Kroppenstedt ${ }^{4}$ \\ and Yuzuru Mikami ${ }^{1}$ \\ ${ }^{1,2,3}$ Research Center for Pathogenic Fungi and Microbial Toxicoses ${ }^{1}$, Clinical Laboratory Chiba \\ University Hospital ${ }^{2}$ and Department of Laboratory Medicine, Chiba University School of \\ Medicine $^{3}$, Chiba University, 1-8-1, Inohana, Chuo-ku, Chiba 260-8673, Japan \\ ${ }^{4}$ Deutsche Sammlung von Mikroorganismen und Zellkulturen, Braunschweig, Germany
}

Correspondence

Yuzuru Mikami

mikami@faculty.chiba-u.jp
The taxonomic positions of two clinically isolated actinomycetes were established using a polyphasic approach. The two strains, IFM $10032^{\top}$, isolated from ear discharge of a 28 -year-old Japanese female patient with external otitis, and IFM 10148, isolated from pleural fluid of a 60-year-old Japanese male patient with bronchitis, possessed meso-diaminopimelic acid as the diagnostic amino acid, MK- $9\left(\mathrm{H}_{2}\right)$ as the predominant menaquinone and mycolic acids ranging from 58 to 64 carbons. The $16 \mathrm{~S}$ rRNA gene sequences of the two strains were most closely related to those of Gordonia aichiensis, Gordonia sputi and 'Gordonia jacobaea'. Differences in several phenotypic characteristics together with genotypic distinctiveness distinguish strains IFM $10032^{\top}$ and IFM 10148 from these three species. DNA-DNA hybridization results and the combination of genotypic and phenotypic data showed that the two strains belong to a single species, and merit recognition of a novel species within the genus Gordonia. The name proposed for this taxon is Gordonia otitidis sp. nov.; the type strain is IFM $10032^{\top}\left(=\mathrm{DSM} 44809^{\top}=\mathrm{JCM}\right.$ $12355^{\top}=\operatorname{NBRC} 100426^{\top}$ ).
The genus Gordonia belongs phylogenetically to the suborder Corynebacterineae (Stackebrandt et al., 1997). Gordonia includes around 20 species (Arenskotter et al., 2005), among which Gordonia terrae has been considered to be a cause of primary cutaneous infection, and Gordonia aichiensis, Gordonia bronchialis and Gordonia rubropertincta have been isolated from sputum specimens of patients with pulmonary disease. Gordonia sputi was also isolated from the sputa of patients with chronic pulmonary diseases (Klatte et al., 1994). Therefore, most of the Gordonia species described hitherto have been considered as opportunistic pathogens in humans (Tsukamura, 1971, 1978, 1982). However, most of the species of Gordonia recently described were isolated from the environment, and have been reported to play important roles in bioremediation or the

Published online ahead of print on 15 April 2005 as DOI 10.1099/ ijs.0.63282-0.

\footnotetext{
Abbreviation: DAP, diaminopimelic acid.

The GenBank/EMBL/DDBJ accession numbers for the 16S rRNA gene sequences of IFM $10032^{\top}$ and IFM 10148 are AB122026 and AB122027, respectively.

Detailed physiological properties of strains IFM $10032^{\top}$ and IFM 10148 and representative Gordonia species are given in supplementary tables in IJSEM Online.
}

biodegradation of pollutants (Linos et al., 1999, 2002; Maldonado et al., 2003; Kim et al., 2000, 2003; Xue et al., 2003; Yoon et al., 2000).

Two hundred and thirty-five strains of pathogenic actinomycetes were isolated from clinical specimens in Japan from 2000 to 2003 and referred to our research centre for identification. Of the 235 isolates, 15 strains were found to belong to Gordonia species. From these 15 isolates, strains IFM $10032^{\mathrm{T}}$ and IFM 10148 were chosen for identification. Based on 16S rRNA gene sequence analysis these two strains are most closely related to G. aichiensis, G. sputi and 'Gordonia jacobaea' (de Miguel et al., 2000). The proposed type strain of ' $G$. jacobaea', MV-1 (=IFM 10484), was also obtained and used for comparative purposes. Comparative DNA-DNA relatedness data showed that strains IFM $10032^{\mathrm{T}}$ and IFM 10148 belong to the same species, but are distinct from G. aichiensis, G. sputi and ' $G$. jacobaea'. Based on our phenotypic and genotypic data, the clinical isolates represent a novel species within the genus Gordonia, for which the name Gordonia otitidis sp. nov. is proposed.

Strains IFM $10032^{\mathrm{T}}$ and IFM 10148 were isolated in 2000 from ear discharge of a 28-year-old Japanese female patient with external otitis, and in 2002 from pleural fluid of a 60year-old Japanese male patient with bronchitis, respectively. 
Both strains were isolated on blood agar plates at $37^{\circ} \mathrm{C}$ for 7 days.

Strains IFM $10032^{\mathrm{T}}$, IFM 10148, G. aichiensis IFMO473 ${ }^{\mathrm{T}}, \mathrm{G}$. sputi IFM $0477^{\mathrm{T}}$ and ' $G$. jacobaea' IFM 10484 were cultured on Muller-Hinton II (MH II; Difco) agar slants with $1 \%$ glucose and $1 \%$ glycerol for 1 week at $27^{\circ} \mathrm{C}$. For extraction of DNA and sequencing, bacterial strains were cultured in a $1 \%$ glucose containing brain heart infusion (BHI; Difco) broth. Morphological observations under a scanning electron microscope (model S-5200; Hitachi) were made on cultures grown on BHI agar.

Carbon source utilization tests were performed as described by Takeuchi \& Hatano (1998). Biochemical characterization of the isolates was performed using the Biolog GP2 MicroPlate assay (Biolog). A modified Ziehl-Nielsen method was used for acid-fast staining test. Whole-cell hydrolysates were analysed for diaminopimelic acid (DAP) isomers using TLC (Staneck \& Roberts, 1974). Wholecell sugars were prepared as detailed by Lechevalier \& Lechevalier (1980) and were analysed by a TLC method (Miyadoh, 2001). Fatty acid methyl esters and mycolic acid trimethylsilyl ethers were prepared and analysed as described by Klatte et al. (1994) using the standard Microbial Identification System (MIDI Inc.) for automated GC analyses (Sasser, 1990; Kämpfer \& Kroppenstedt, 1996). Menaquinones were extracted from freeze-dried biomass and analysed as described by Chun \& Goodfellow (1995).

Preparation of genomic DNA samples for sequencing was performed using the guanidine thiocyanate method of Kageyama et al. (2004a, b).

$16 \mathrm{~S}$ rRNA genes were amplified and sequenced by PCR employing six prokaryotic $16 \mathrm{~S}$ rRNA gene universal primers. PCR was performed with a DNA thermal cycler (TaKaRa) using 35 cycles of denaturation at $94^{\circ} \mathrm{C}$ for $60 \mathrm{~s}$, primer annealing at $60^{\circ} \mathrm{C}$ for $60 \mathrm{~s}$ and primer extension at $72{ }^{\circ} \mathrm{C}$ for $120 \mathrm{~s}$. DNA sequences were determined with an automatic sequence analyser (ABI PRISM 3100; PE Applied Biosystems) using the BigDye terminator cycle sequencing ready reaction kit (PE Applied Biosystems). The 16S rRNA gene sequences were analysed and species related to the isolates were identified by performing a BLAST sequence database search. Nucleotide 200 substitution rates ( $K_{\text {nuc }}$ values) were calculated (Kimura \& Ohta, 1972). Phylogenetic trees were constructed by the neighbourjoining method (Saitou \& Nei, 1987), and the topology of the trees was evaluated by a bootstrap analysis of the sequence data using CLUSTAL W software (Thompson et al., 1994).

Preparation of genomic samples for DNA-DNA hybridization was performed using a modified method of that described by Saito \& Miura (1983). DNA base compositions were estimated by HPLC (Tamaoka \& Komagata, 1984) and levels of DNA-DNA relatedness were determined by the method of Ezaki et al. (1989), using photobiotin and microplates.

Whole-cell hydrolysates of strains IFM $10032^{\mathrm{T}}$ and IFM 10148 contained meso-DAP as the only diamino acid of the peptidoglycan and arabinose plus galactose as major wholecell sugars. The fatty acid pattern of strain IFM $10032^{\mathrm{T}}$ comprised straight-chain saturated and unsaturated fatty acids plus tuberculostearic acid (Table 1). Although this pattern is roughly the same in all gordoniae, there are qualitative and quantitative species-specific and often intraspecific differences (Klatte et al., 1994) (Table 1). The predominant menaquinone is MK- $9\left(\mathrm{H}_{2}\right)$, but substantial amounts of MK- $8\left(\mathrm{H}_{2}\right)$ are also present. The $\mathrm{G}+\mathrm{C}$ contents of the DNA of strains IFM $10032^{\mathrm{T}}$ and IFM 10148 are $64 \cdot 9$ and $65 \cdot 2 \mathrm{~mol} \%$, respectively.

The above results indicated that strains IFM $10032^{\mathrm{T}}$ and IFM 10148 have properties consistent with their assignment to the genus Gordonia (Minnikin et al., 1980; Stackebrandt et al., 1988; Klatte et al., 1994).

Strains IFM $10032^{\mathrm{T}}$ and IFM 10148 produced short elementary branching hyphae that disintegrated into rod- and cocci-like elements. They showed the typical rod-coccus growth cycle that is usually found among strains of the genus Gordonia and related taxa (Goodfellow, 1992).

Table 1. Fatty acid profiles of strain IFM $10032^{\top}$ and types strains of its closest phylogenetic relatives

Strains: 1, G. otitidis IFM $10032^{\mathrm{T}} ; 2$, G. aichiensis IFM $0473^{\mathrm{T}} ; 3$, G. sputi IFM $0477^{\mathrm{T}}$; 4 , 'G. jacobaea' IFM 10484. Values are percentages of total fatty acids; -, not detected. Abbreviations are exemplified by the following: cis-7-16:1, cis-7 hexadecenoic acid (palmitoleic acid); 10-methyl 18:0, 10-methyl octadecanoic acid (tuberculostearic acid).

\begin{tabular}{|lcccc|}
\hline Fatty acid & $\mathbf{1}$ & $\mathbf{2}$ & $\mathbf{3}$ & $\mathbf{4}$ \\
\hline $10: 0$ & - & - & $0 \cdot 50$ & $0 \cdot 57$ \\
ECL $13 \cdot 957^{*}$ & $0 \cdot 61$ & $0 \cdot 76$ & - & $0 \cdot 54$ \\
$14: 0$ & $2 \cdot 26$ & $1 \cdot 95$ & $2 \cdot 9$ & $1 \cdot 21$ \\
cis-10-15:1 & $0 \cdot 51$ & $0 \cdot 37$ & - & $0 \cdot 17$ \\
$15: 0$ & $1 \cdot 07$ & $0 \cdot 84$ & - & $0 \cdot 3$ \\
cis-7-16:1 & $0 \cdot 56$ & $0 \cdot 46$ & $1 \cdot 02$ & $0 \cdot 23$ \\
cis-9-16:1 & $18 \cdot 91$ & $17 \cdot 66$ & - & $20 \cdot 29$ \\
$16: 0$ & $31 \cdot 65$ & $35 \cdot 95$ & $52 \cdot 74$ & $34 \cdot 66$ \\
cis-9-17:1 & $1 \cdot 45$ & $0 \cdot 43$ & $0 \cdot 75$ & $1 \cdot 16$ \\
$17: 0$ & $1 \cdot 1$ & $0 \cdot 78$ & $1 \cdot 45$ & $0 \cdot 4$ \\
$10-$ methyl $17: 0$ & $0 \cdot 25$ & - & - & $0 \cdot 15$ \\
cis-9-18:1 & $15 \cdot 19$ & $5 \cdot 52$ & $19 \cdot 14$ & $19 \cdot 64$ \\
$18: 0$ & $3 \cdot 13$ & $4 \cdot 75$ & $2 \cdot 32$ & $0 \cdot 55$ \\
$10-$-methyl $18: 0$ & $22 \cdot 96$ & $30 \cdot 53$ & $19 \cdot 19$ & $20 \cdot 14$ \\
cis-9-19:1 & $0 \cdot 34$ & - & - & - \\
\hline
\end{tabular}

*Unknown lipid eluting at a equivalent chain length of 13.957. 
Table 2. Main mycolic acid components of G. otitidis sp. nov. IFM $10032^{\top}$ and other type strains of Gordonia species

Values are percentages of total mycolic acids. Designations indicate the chain lengths of the mycolic acids, i.e. number of carbon atoms.

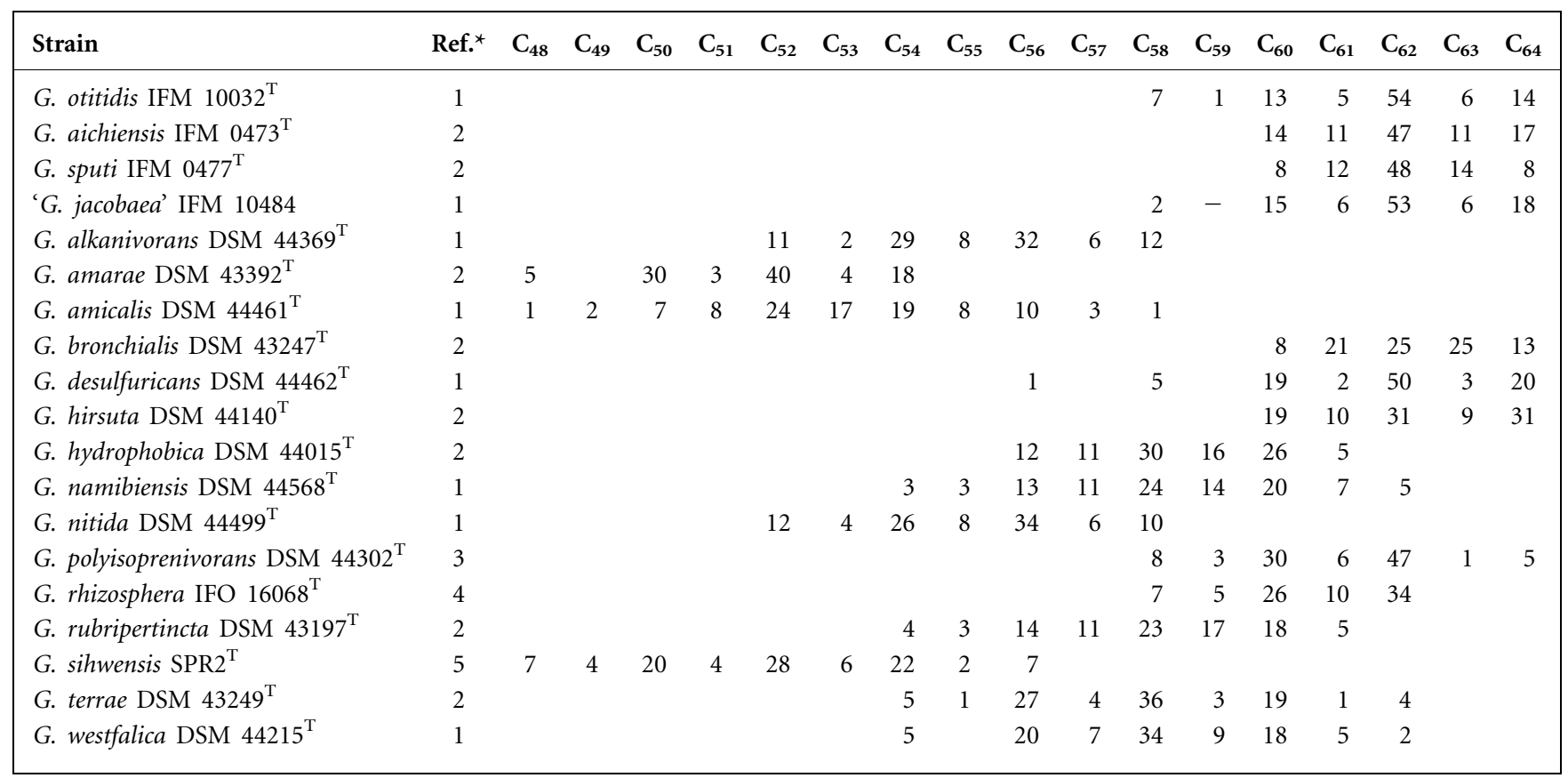

${ }^{\star}$ Data were taken from: 1, this study; 2, Klatte et al. (1994); 3, Linos et al. (1999); 4, Takeuchi \& Hatano (1998); 5, Kim et al. (2003).

The mycolic acid pattern of strain IFM $10032^{\mathrm{T}}$ is similar to those of G. aichiensis, G. sputi, Gordonia desulfuricans, 'G. jacobaea' and Gordonia polyisoprenivorans, which possess similar sized mycolic acids of chain length of about $\mathrm{C}_{58^{-}}$ $\mathrm{C}_{64}$ and with the principal mycolic acid $\mathrm{C}_{62}$ comprising about $50 \%\left(54 \%\right.$ for IFM $\left.10032^{\mathrm{T}}\right)$ of the total (Table 2$)$.

Almost complete 16S rRNA gene sequences of strains IFM $10032^{\mathrm{T}}$ and IFM 10148 were determined and compared with those of other Gordonia species. Highest sequence similarity of strain IFM $10032^{\mathrm{T}}$ was $99 \cdot 5 \%$ to G. aichiensis IFM $0473^{\mathrm{T}}$ $(1454 / 1561 \mathrm{nt})$, followed by $99 \cdot 4 \%(1452 / 1461)$ and $99 \cdot 3 \%$ $(1453 / 1463 \mathrm{nt})$ to G. sputi IFM $0477^{\mathrm{T}}$ and 'G. jacobaea' IFM 10484, respectively.

The phylogenetic tree shown in Fig. 1 based on the $16 \mathrm{~S}$ rRNA gene sequences shows that strains IFM $10032^{\mathrm{T}}$ and IFM 10148 cluster with G. aichiensis IFM $0473^{\mathrm{T}}$, G. sputi IFM $0477^{\mathrm{T}}$ and ' $G$. jacobaea' IFM 10484.

Levels of DNA-DNA relatedness between IFM $10032^{\mathrm{T}}$ and IFM 10148 were 94.7 and $95 \cdot 3 \%$, respectively, confirming that the two strains belong to the same species. Relatedness levels of strain IFM $10032^{\mathrm{T}}$ to G. aichiensis IFM $0473^{\mathrm{T}}, G$. sputi IFM $0477^{\mathrm{T}}$ and ' $G$. jacobaea' IFM 10484 were $31 \cdot 1,3 \cdot 8$ and $19 \cdot 7 \%$, respectively. All these values are well below the $70 \%$ cut-off recommended by Wayne et al. (1987) for the delineation of separate species.

Results of physiological tests obtained from growth on agar plates revealed that strains IFM $10032^{\mathrm{T}}$ and IFM 10148 were able to utilize 18 out of 32 carbon sources. Strains IFM $10032^{\mathrm{T}}$ and IFM 10148 gave identical responses in

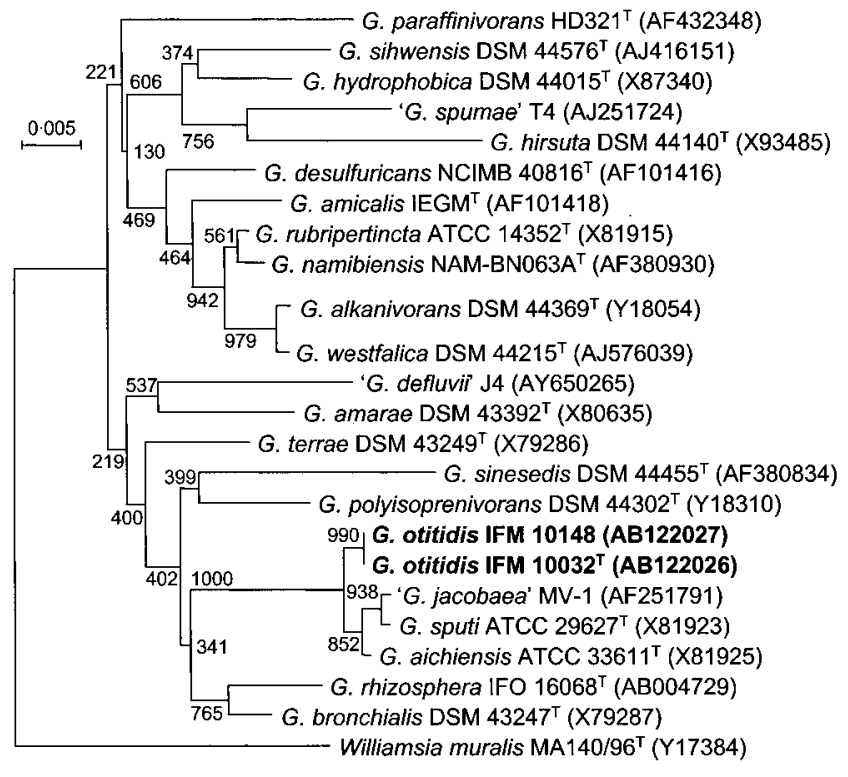

Fig. 1. Phylogenetic tree based on $16 \mathrm{~S}$ rRNA gene sequences showing the phylogenetic positions of strains IFM $10032^{\top}$ and IFM 10148 and type strains of Gordonia species. The tree was created using the neighbour-joining method and $K_{\text {nuc }}$ values. Bootstrap values (from 1000 replications) are shown at branch points. Bar, $0.005 K_{\text {nuc }}$ value. 
Table 3. Compound utilization patterns that distinguish strains of $G$. otitidis sp. nov. from $G$. aichiensis, $G$. sputi and 'G. jacobaea'

Taxa: 1, G. otitidis strains IFM $10032^{\mathrm{T}}$ and IFM 10148; 2, G. aichiensis IFM $0473^{\mathrm{T}}$; 3, G. sputi IFM $0477^{\mathrm{T}}$; 4, 'G. jacobaea' IFM 10484. +, Positive; -, negative; ND, not determined. All four taxa are negative for utilization of 3-hydroxybenzoate.

\begin{tabular}{|c|c|c|c|c|}
\hline Compound & 1 & 2 & 3 & 4 \\
\hline D-Ribose & - & - & - & + \\
\hline Sucrose & + & - & - & + \\
\hline D-Turanose & + & - & - & + \\
\hline D-Arabitol & + & - & + & + \\
\hline$N$-Acetyl-D-glucosamine & + & - & - & - \\
\hline Caprate & - & + & + & $\mathrm{ND}$ \\
\hline 4-Aminobutyrate & + & + & - & ND \\
\hline Succinate & - & - & + & + \\
\hline 4-Hydroxybenzonate & + & - & - & - \\
\hline Quinate & + & + & - & ND \\
\hline L-Alanine & + & + & - & + \\
\hline L-Aspartate & - & + & - & - \\
\hline L-Leucine & + & - & - & + \\
\hline L-Proline & + & - & - & + \\
\hline L-Serine & + & - & - & + \\
\hline L-Valine & + & - & - & + \\
\hline Putrescine & + & - & - & + \\
\hline Tyramine & - & - & - & + \\
\hline Acetamide & + & - & - & $\mathrm{ND}$ \\
\hline
\end{tabular}

carbon utilization tests (Table 3). Some carbon utilization patterns useful for identifying and differentiating strains IFM $10032^{\mathrm{T}}$ and type strains of other species of the genus Gordonia are given in Table 3 and under the species description below. The utilization pattern clearly showed that IFM $10032^{\mathrm{T}}$ could be differentiated from $G$. aichiensis IFM $0473^{\mathrm{T}}$, G. sputi IFM $0477^{\mathrm{T}}$ and ' $G$. jacobaea' IFM 10484.

Representative biochemical characterization using the Biolog GP2 assay system for IFM $10032^{\mathrm{T}}$ and IFM 10148 is shown in Table 4 (see also Supplementary Table S2), and also confirmed that IFM $10032^{\mathrm{T}}$ could be differentiated from G. sputi IFM $0477^{\mathrm{T}}$, G. aichiensis IFM $0473^{\mathrm{T}}$ and ' $G$. jacobaea' IFM 10484.

These results indicate that strain IFM $10032^{\mathrm{T}}$ merits recognition as representing a novel species of Gordonia (Stackebrandt \& Goebel, 1994). Based on the source of isolation, from a patient with external otitis, the name Gordonia otitidis sp. nov. is proposed.

Because the name ' $G$. jacobaea' has not been validly published in IJSEM in accordance with Rule 27 of the Bacteriological Code, the present studies included characterization of the proposed type strain of 'G. jacobaea', MV-1 (=IFM $10484=$ DSM $44880=$ JCM 12643).
Table 4. Selected results of Biolog GP2 assays

Taxa: 1, G. otitidis strains IFM $10032^{\mathrm{T}}$ and IFM 10148; 2, G. aichiensis IFM $0473^{\mathrm{T}}$; 3, G. sputi IFM $0477^{\mathrm{T}}$; 4, 'G. jacobaea' IFM 10484. +, Positive; -, negative. Only those compounds that are most useful for discriminating G. otitidis from related species are shown; more complete results are available as Supplementary Table S2 in IJSEM Online.

\begin{tabular}{|c|c|c|c|c|}
\hline Compound & 1 & 2 & 3 & 4 \\
\hline$\alpha$-Cyclodextrin & - & + & - & - \\
\hline$\beta$-Cyclodextrin & - & + & - & - \\
\hline Dextrin & + & + & + & - \\
\hline Glycogen & + & + & - & - \\
\hline Inulin & + & - & - & - \\
\hline$N$-Acetyl-D-mannosamine & - & + & - & - \\
\hline Amygdalin & - & + & - & - \\
\hline Maltose & + & + & + & - \\
\hline Maltotriose & + & + & + & - \\
\hline D-Mannitol & - & - & + & - \\
\hline D-Melibiose & - & + & + & - \\
\hline 3-Methyl glucose & - & + & - & - \\
\hline D-Trehalose & + & + & + & - \\
\hline$\beta$-Hydroxybutyric acid & - & + & - & + \\
\hline Methyl pyruvate & + & - & + & + \\
\hline Monomethyl succinate & - & + & - & - \\
\hline Pyruvic acid & + & - & - & + \\
\hline Succinamic acid & - & + & - & - \\
\hline Succinic acid & - & + & - & - \\
\hline D-Alanine & + & - & + & - \\
\hline L-Alanyl glycine & + & + & + & - \\
\hline L-Asparagine & - & - & + & - \\
\hline L-Glutamic acid & - & + & + & - \\
\hline Adenosine $5^{\prime}$-monophosphate & - & + & + & - \\
\hline Thymidine $5^{\prime}$-monophosphate & - & + & + & - \\
\hline Uridine $5^{\prime}$-monophosphate & - & + & + & - \\
\hline Fructose 6-phosphate & - & + & + & - \\
\hline Glucose 1-phosphate & - & + & + & - \\
\hline Glucose 6-phosphate & - & + & + & - \\
\hline
\end{tabular}

\section{Description of Gordonia otitidis sp. nov.}

Gordonia otitidis (o.ti'ti.dis. N.L. gen. n. otitidis of otitis, inflammation of the ear).

Aerobic, Gram-positive, partially acid-fast, nitrate-reducing, non-motile actinomycetes that form rod/coccus-like elements $(0 \cdot 6-0 \cdot 8 \times 2 \cdot 5-3 \cdot 1 \mu \mathrm{m})$. Colonies are white, changing with time to apricot to pale orange. Colonies of the type strain are rough with irregular margins. Utilizes sucrose, D-turanose, D-arabitol, $\mathrm{N}$-acetyl-D-glucosamine, 4aminobutyrate, 2-hydroxyvalerate, 2-oxoglutarate, pimelate, benzoate, 4-hydroxybenzoate, phenylacetate, quinate, L-alanine, L-leucine, L-proline, L-serine, L-valine, putrescine and acetamide. Does not utilize D-galactose, L-rhamnose, D-ribose, $i$-inositol, glucarate, gluconate, caprate, succinate, 3-hydroxybenzoate, citrate, L-aspartate or tyramine. Wholecell hydrolysates contain meso-DAP, arabinose and galactose 
(cell-wall chemotype IV sensu Lechevalier \& Lechevalier, 1980). Predominant menaquinone is MK- $9\left(\mathrm{H}_{2}\right)$; a small amount of MK-8 $\left(\mathrm{H}_{2}\right)$ is also present. Principal mycolic acids have a chain length (58-64 carbons) equivalent to those of other Gordonia species. Physiological properties are given in Supplementary Table S1 available in IJSEM Online. The type strain is a clinical isolate. The $\mathrm{G}+\mathrm{C}$ content of the DNA is $64 \cdot 9-65 \cdot 2 \%$.

The type strain, IFM $10032^{\mathrm{T}}\left(=\mathrm{DSM} \quad 44809^{\mathrm{T}}=\mathrm{JCM}\right.$ $12355^{\mathrm{T}}=$ NBRC $100426^{\mathrm{T}}$ ), was isolated from ear discharge of a patient with external otitis, Japan.

\section{Acknowledgements}

We thank Drs T. Tamura and K. Suzuki (National Institute of Technology and Evaluation, NITE-BRC, Japan) for advice on scanning electron microscopic observation.

\section{References}

Arenskotter, M., Linos, A., Schumann, P., Kroppenstedt, R. M. \& Steinbuchel, A. (2005). Gordonia nitida Yoon et al. 2000 is a later synonym of Gordonia alkanivorans Kummer et al. 1999. Int J Syst Evol Microbiol 55, 695-697.

Chun, J. \& Goodfellow, M. (1995). A phylogenetic analysis of genus Nocardia with 16S rRNA gene sequences. Int J Syst Bacteriol 45, 240-245.

de Miguel, T., Sieiro, C., Poza, M. \& Villa, T. G. (2000). Isolation and taxonomic study of a new canthaxanthin-containing bacterium, Gordonia jacobaea MV-1 sp. nov. Int Microbiol 3, 107-111.

Ezaki, T., Hashimoto, Y. \& Yabuuchi, E. (1989). Fluorometric deoxyribonucleic acid-deoxyribonucleic acid hybridization in microdilution wells as an alternative to membrane filter hybridization in which radioisotopes are used to determine genetic relatedness among bacterial strains. Int J Syst Bacteriol 39, 224-229.

Goodfellow, M. (1992). The family Nocardiaceae. In The Prokaryotes, 2nd edn, pp. 1188-1213. Edited by A. Balows, H. G. Trüper, M. Dworkin, W. Harder \& K. H. Schleifer. New York: Springer.

Kageyama, A., Poonwan, N., Yazawa, K., Mikami, Y. \& Nishimura, K. (2004a). Nocardia asiatica sp. nov., isolated from patients with nocardiosis in Japan and clinical specimens from Thailand. Int J Syst Evol Microbiol 54, 125-130.

Kageyama, A., Yazawa, K., Nishimura, K. \& Mikami, Y. (2004b). Nocardia inohanensis sp. nov., Nocardia yamanashiensis sp. nov. and Nocardia niigatensis sp. nov., isolated from clinical specimens. Int J Syst Evol Microbiol 54, 563-569.

Kämpfer, P. \& Kroppenstedt, R. M. (1996). Numerical analysis of fatty acid patterns of coryneform bacteria and related taxa. Can J Microbiol 42, 989-1005.

Kim, S. B., Brown, R., Oldfield, C., Gilbert, S. C., lliarionov, S. \& Goodfellow, M. (2000). Gordonia amicalis sp. nov., a novel dibenzothiophene-desulphurizing actinomycete. Int $J$ Syst Evol Microbiol 50, 2031-2036.

Kim, K. K., Lee, C. S., Kroppenstedt, R. M., Stackebrandt, E. \& Lee, S. T. (2003). Gordonia sihwensis sp. nov., a novel nitrate-reducing bacterium from a wastewater-treatment bioreactor. Int J Syst Evol Microbiol 53, 1427-1433.

Kimura, M. \& Ohta, T. (1972). On the stochastic model for estimation of mutational distance between homologous proteins. J Mol Evol 2, 87-90.
Klatte, S., Rainey, F. A. \& Kroppenstedt, R. M. (1994). Transfer of Rhodococcus aichiensis Tsukamura 1982 and Nocardia amarae Lechevalier and Lechevalier 1974 to the genus Gordona as Gordona aichiensis comb. nov. and Gordona amarae comb. nov. Int J Syst Bacteriol 44, 769-773.

Lechevalier, M. P. \& Lechevalier, H. A. (1980). The chemotaxonomy of actinomycetes. In Actinomycete Taxonomy, pp. 227-291. Edited by A. Dietz \& D. W. Thayer. Fairfax, VA: Society for Industrial Microbiology.

Linos, A., Steinbuchel, A., Spröer, C. \& Kroppenstedt, R. M. (1999). Gordonia polyisoprenivorans sp. nov., a rubber-degrading actinomycete isolated from an automobile tyre. Int J Syst Bacteriol 49, 1785-1791.

Linos, A., Berekaa, M. M., Steinbuchel, A., Kim, K. K., Spröer, C. \& Kroppenstedt, R. M. (2002). Gordonia westfalica sp. nov., a novel rubber-degrading actinomycete. Int J Syst Evol Microbiol 52, 1133-1139.

Maldonado, L. A., Stainsby, F. M., Ward, A. C. \& Goodfellow, M. (2003). Gordonia sinesedis sp. nov., a novel soil isolate. Antonie van Leeuwenhoek 83, 75-80.

Minnikin, D. E., Hutchinson, I. G., Caldicott, A. B. \& Goodfellow, M. (1980). Thin-layer chromatography of methanolysates of mycolic acid-containing bacteria. J Chromatogr 188, 221-233.

Miyadoh, M. (2001). Identification procedure at the genus level. In Identification Manual of Actinomycetes, pp. 9-19. Edited by S. Miyadoh, M. Hamada, K. Hotta, T. Kudo, A. Seino, K. Suzuki \& A. Yokota. Tokyo: Business Center for Academic Societies.

Saito, H. \& Miura, K. (1983). Preparation of transforming deoxyribonucleic acid by phenol treatment. Biochim Biophys Acta 72, 619-629.

Saitou, N. \& Nei, M. (1987). The neighbor-joining method: a new method for reconstructing phylogenetic trees. Mol Biol Evol 4, 406-425.

Sasser, M. (1990). Identification of bacteria by gas chromatography of cellular fatty acids. USFCC Newsl 20, 1-6.

Stackebrandt, E. \& Goebel, B. M. (1994). Taxonomic note: place for DNA-DNA reassociation and 16S rRNA sequence analysis in the present species definition in bacteriology. Int J Syst Bacteriol 44, 846-849.

Stackebrandt, E., Rainey, F. A. \& Ward-Rainey, N. L. (1988). Evidence of phylogenetic heterogeneity within the genus Rhodococcus: revival of the genus Gordona (Tsukamura). J Gen Appl Microbiol 34, 341-348.

Stackebrandt, E., Rainey, F. A. \& Ward-Rainey, N. L. (1997). Proposal for a new hierarchic classification system, Actinobacteria classis nov. Int J Syst Bacteriol 47, 479-491.

Staneck, J. L. \& Roberts, G. D. (1974). Simplified approach to identification of aerobic actinomycetes by thin-layer chromatography. Appl Microbiol 28, 226-231.

Takeuchi, M. \& Hatano, K. (1998). Gordonia rhizosphera sp. nov. isolated from the mangrove rhizosphere. Int J Syst Bacteriol 48, 907-912.

Tamaoka, J. \& Komagata, K. (1984). Determination of DNA base composition by reversed-phase high-performance liquid chromatography. FEMS Microbiol Lett 25, 125-128.

Thompson, J. D., Higgins, D. G. \& Gibson, T. J. (1994). CLUSTAL W: improving the sensitivity of progressive multiple sequence alignment through sequence weighting, position-specific gap penalties and weight matrix choice. Nucleic Acids Res 22, 4673-4680.

Tsukamura, M. (1971). Proposal of new genus, Gordona, for slightly acid-fast organisms occurring in sputa of patients with pulmonary disease and in soil. J Gen Microbiol 68, 15-26. 
Tsukamura, M. (1978). Numerical classification of Rhodococcus (formerly Gordona) organisms recently isolated from sputa of patients; description of Rhodococcus sputi Tsukamura sp. nov. Int J Syst Bacteriol 28, 169-181.

Tsukamura, M. (1982). Numerical analysis of the taxonomy of nocardiae and rhodococci. Division of Nocardia asteroides sensu stricto into two species and descriptions of Nocardia paratuberculosis sp. nov. Tsukamura (formerly the Kyoto-I group of Tsukamura), Nocardia nova sp. nov. Tsukamura, Rhodococcus aichiensis sp. nov. Tsukamura, Rhodococcus chubuensis sp. nov. Tsukamura, and Rhodococcus obuensis sp. nov. Tsukamura. Microbiol Immunol 26, 1101-1119.
Wayne, L. G., Brenner, D. J., Colwell, R. R. \& 9 other authors (1987). Report of the ad hoc committee on reconciliation of approaches to bacterial systematics. Int $J$ Syst Bacteriol 37, 463-464.

Xue, Y., Sun, X., Zhou, P., Liu, R., Liang, F. \& Ma, Y. (2003). Gordonia paraffinivorans sp. nov., a hydrocarbon-degrading actinomycete isolated from an oil-producing well. Int J Syst Evol Microbiol 53, 1643-1646.

Yoon, J.-H., Lee, J. J., Kang, S.-S., Takeuchi, M., Shin, Y. K., Lee, S. T., Kang, K. H. \& Park, Y.-H. (2000). Gordonia nitida sp. nov., a bacterium that degrades 3-ethylpyridine and 3-methylpyridine. Int J Syst Evol Microbiol 50, 1203-1210. 